\title{
FAKTOR YANG MEMPENGARUHI KEJADIAN ISPA PADA BAYI USIA 4 SAMPAI 6 BULAN
}

\author{
Vedjia Medhyna ${ }^{1}$ \\ ${ }^{1}$ Prodi DIII Kebidanan, STIKes Fort De Kock Bukittinggi, Jl. Soekarno Hatta, Kelurahan Manggis Ganting, Kec \\ Mandiangin Koto Selayan \\ email: vedjiamedhyna@gmail.com
}

Submitted: 19-1-2017, Reviewer: 03-05-2017, Accepted: 18-9-2017

\begin{abstract}
Infeksi Saluran Pernapasan Akut masih merupakan salah satu penyebab kematian pada bayi di Indonesia yaitu sebesar 12,7\% Kejadian ISPA pada bayi dipengaruhi oleh banyak faktor. Adapun tujuan penelitian ini untuk mengetahui faktor yang mempengaruhi kejadian ISPA di wilayah kerja Puskesmas Kabupaten Pasaman.Penelitian ini menggunakan disain kohort, pengumpulan data dengan menggunakan kuesioner terhadap 175 bayi sebagai sampel untuk mengetahui jenis kelamin, status menyusui, status imunisasi, status gizi, pendidikan ibu, pekerjaan ibu, penghasilan keluarga, kebiasaan merokok, keadaan ventilasi rumah, jenis lantai, ventilasi dapur, kepadatan hunian, bahan bakar masak dan kejadian ISPA. Hasil analisis bivariat diketahui penyebab kejadian ISPA adalah status menyusui $(p=0,001)$, status gizi $(p=0,048)$, status imunisasi $(p=0,048)$, penghasilan keluarga $(p=0,020)$, ventilasi $(p=0,004)$, jenis lantai $(p=0,035)$, kepadatan hunian $(p=0,039)$, dan ventilasi dapur $(p=0,038)$. Analisis multivariat didadapkan status menyusui merupakan faktor paling dominan ( $p=0,000$, OR=7,036). Menyusukan secara eksklusif sangat mempengaruhi kejadian ISPA, disarankan kepada tenaga kesehatan lebih gencar memberikan penyuluhan pentingnya ASI eksklusif kepada masyarakat khususnya ibu hamil trimester tiga.
\end{abstract}

Keywords: $\quad$ status menyusui, status gizi, keadaan ventilasi rumah, jenis lantai, ISPA

\begin{abstract}
Acute Respiratory Infection it still is one of cause of death in infants in Indonesia of 12,7\%. Acute Respiratory Infection in the infant influence many factor. The purpose of this study is to define the correlation of breastfeeding status with growth of infant and predisposing factors with ARI at the Health Care in Pasaman Region.This study used cohort design, the collection of data using questionnaires against 175 infants as a sample to find out the gender, breastfeeding status, immunization status, nutritional status, maternal education, maternal employment, family income, smoking habit, the house ventilation, the floor type, kitchen ventilation, residential density, fuel used to cook and the incidence of ARI. The result of bivariat analysis shows that brestfeeding status associated with the growth $p(0,032)$, and the factor predisposing occurence of ARI was breastfeeding status $(p=0.001)$, nutrition status $(p=$ $0,048)$, immunization status ( $p=0,048)$, family income $(p=0,020)$, ventilation $(p=0,004)$, floors type $(p$ $=0,035)$, residential density $(p=0,039)$, and kitchen ventilation $(p=0,038)$. Multivariate analysisshowsthat the status of breastfeeding is the most dominant factor $(p=0.000, O R=7,036)$.It can be concluded that exclusive breastfeeding give many affects of URI, advised to health professionals to be more aggressive promoting about how important exclusive breastfeeding is to the society especially to third-trimester-pregnant woman
\end{abstract}

Keywords: breastfeeding status, nutritional status, the house ventilation, the floor type, Acute Respiratory Infection 


\section{PENDAHULUAN}

Berdasarkan data dari SDKI tahun 2012, angka kematian bayi di Indonesia 32 kematian per 1.000 kelahiran hidup, dan di Sumatera Barat 27 kematian per 1.000 kelahiran hidup. Di Indonesia, ISPA masih merupakan salah satu penyebab kematian pada bayi sebesar 12,7\%. Di Indonesia ISPA merupakan salah satu penyebab utama kunjungan pasien ke sarana kesehatan, 40$70 \%$ anak berobat ke Rumah Sakit adalah penderita ISPA. ${ }^{1}$

Menurut teori adapun faktor yang mempengaruhi ISPA antara lain status gizi, pemberian ASI eksklusif, kelengkapan imunisasi, jenis kelamin, kepadatan hunian, ventilasi, jenis lantai, ventilasi dapur, bahan bakar masak, anggota keluarga perokok, pendidikan ibu, pekerjaan ibu, serta penghasilan keluarga. ${ }^{2}$

Berdasarkan latar belakang diatas, maka peneliti tertarik untuk melakukan penelitian tentang faktor yang mempengaruhi kejadian ISPA pada bayi usia 4 sampai 6 bulan.

\section{METODE PENELITIAN}

Penelitian ini merupakan penelitian prospektif dengan pendekatan kohort study.(diikuti selama 3 bulan) dengan sampel penelitian adalah ibu yang mempunyai bayi usia 4 bulan sebanyak 175 bayi. Sampel diambil dengan multistage sampling. Penelitian dilakukan di Wilayah kerja Puskesmas Kabupaten Pasaman. Pengumpulan data dengan melakukan wawancara melalui kuesioner. Penelitian ini dilakukan mulai bulan April 2015 hingga Juni 2016. Variabel Independent penelitian adalah status menyusui, status gizi, imunisasi, jenis kelamin, pendidikan, pekerjaan, penghasilan, kebidasan merokok, keadaan ventilasi, jenis lantai, bahan bakar memasak, kepadatan hunian, dan variabel dependen adalah kejadian ISPA. Teknik analisis dengan menggunakan SPSS

\section{HASIL DAN PEMBAHASAN}

Hasil penelitian ini akan membahas beberapa variabel, status menyusui, lingkungan fisik, kejadian ISPA

Tabel 1.Analisis Faktor Kejadian ISPA

\begin{tabular}{|c|c|c|c|c|c|c|}
\hline \multirow[t]{3}{*}{ Variabel } & \multicolumn{4}{|c|}{ Kejadia ISPA } & \multirow[t]{3}{*}{$\mathbf{N}$} & \multirow[t]{3}{*}{ P Value } \\
\hline & \multicolumn{2}{|c|}{ Ada } & \multicolumn{2}{|c|}{ Tidak ada } & & \\
\hline & $\mathbf{n}$ & $\%$ & $\mathbf{n}$ & $\%$ & & \\
\hline \multicolumn{7}{|l|}{ Status } \\
\hline \multicolumn{7}{|l|}{ Menyusui : } \\
\hline $\begin{array}{ll}\text { Tidak } & \text { ASI } \\
\text { eksklusif } & \end{array}$ & 73 & 79,3 & 19 & 20,7 & 92 & 0,001 \\
\hline ASI eksklusif & 30 & 36,1 & 53 & 63,9 & 83 & \\
\hline Jumlah & 103 & 58,9 & 72 & 41,1 & 175 & \\
\hline \multicolumn{7}{|l|}{ JK: } \\
\hline Laki-laki & 55 & 61,8 & 34 & 38,2 & 89 & 0,515 \\
\hline Perempuan & 48 & 55,8 & 38 & 44,2 & 86 & \\
\hline Jumlah & 103 & 58,9 & 72 & 41,1 & 175 & \\
\hline \multicolumn{7}{|l|}{ Status Gizi } \\
\hline Tidak normal & 15 & 83,3 & 3 & 16,7 & 18 & 0,048 \\
\hline Normal & 88 & 56,1 & 69 & 43,9 & 157 & \\
\hline Jumlah & 103 & 58,9 & 72 & 41,1 & 175 & \\
\hline \multicolumn{7}{|l|}{ Status } \\
\hline \multicolumn{7}{|l|}{ Imunisasi : } \\
\hline Tidak lengkap & 9 & 90,0 & 1 & 10,0 & 10 & 0,048 \\
\hline Lengkap & 94 & 57,0 & 71 & 43,0 & 165 & \\
\hline Jumlah & 103 & 58,9 & 72 & 41,1 & 175 & \\
\hline \multicolumn{7}{|l|}{ Pendidikan } \\
\hline Rendah & 45 & 65,2 & 24 & 34,8 & 69 & 0,222 \\
\hline Tinggi & 58 & 54,7 & 48 & 45,3 & 106 & \\
\hline Jumlah & 103 & 58,9 & 72 & 41,1 & 175 & \\
\hline \multicolumn{7}{|l|}{ Pekerjaan } \\
\hline Bekerja & 27 & 56,2 & 21 & 43,8 & 48 & 0,796 \\
\hline Tidak bekerja & 76 & 59,8 & 51 & 40,2 & 127 & \\
\hline Jumlah & 103 & 58,9 & 72 & 41,1 & 175 & \\
\hline \multicolumn{7}{|l|}{ Penghasilan } \\
\hline \multicolumn{7}{|l|}{ Keluarga: } \\
\hline$<$ UMR & 38 & 73,1 & 14 & 21,4 & 52 & 0,020 \\
\hline ¿्यMR & 65 & 52,8 & 58 & 50,6 & 123 & \\
\hline Jumlah & 103 & 58,9 & 72 & 41,1 & 175 & \\
\hline \multicolumn{7}{|l|}{$\begin{array}{l}\text { Kebiasaan } \\
\text { merokok: }\end{array}$} \\
\hline Ada & 90 & 60,4 & 59 & 39,6 & 149 & 0,436 \\
\hline Tidak ada & 13 & 50,0 & 13 & 50,0 & 26 & \\
\hline Jumlah & 103 & 58,9 & 72 & 41,1 & 175 & \\
\hline \multicolumn{7}{|l|}{ Ventilasi } \\
\hline TMS & 32 & 80,0 & 8 & 20,0 & 40 & 0,004 \\
\hline MS & 71 & 52,6 & 64 & 47,4 & 135 & \\
\hline Jumlah & 103 & 58,9 & 72 & 41,1 & 175 & \\
\hline \multicolumn{7}{|l|}{ Jenis Lantai : } \\
\hline TMS & 18 & 81,8 & 4 & 18,2 & 22 & 0,035 \\
\hline MS & 85 & 55,6 & 68 & 44,4 & 153 & \\
\hline Jumlah & 103 & 58,9 & 72 & 41,1 & 175 & \\
\hline Kepadatan & & & & & & \\
\hline Hunian : & & & & & & \\
\hline Padat & 36 & 72,0 & 14 & 28,0 & 50 & 0,039 \\
\hline Tdk padat & 67 & 53,6 & 58 & 46,6 & 125 & \\
\hline Jumlah & 103 & 58,9 & 72 & 41,1 & 175 & \\
\hline Ventilasi & & & & & & \\
\hline Dapur : & & & & & & \\
\hline TMS & 31 & 73,8 & 11 & 26,2 & 42 & 0,038 \\
\hline
\end{tabular}




\begin{tabular}{|c|c|c|c|c|c|c|c|}
\hline MS & & 72 & 54,1 & 61 & 45,9 & 133 & \\
\hline Jumlah & & 103 & 58,9 & 72 & 41,1 & 175 & \\
\hline $\begin{array}{l}\text { Bahan } \\
\text { : }\end{array}$ & Bakar & & & & & & \\
\hline TMS & & 45 & 61,6 & 28 & 38,4 & 73 & 0,633 \\
\hline MS & & 58 & 56,9 & 44 & 43,1 & 102 & \\
\hline Jumlah & & 103 & 58,9 & 72 & 41,1 & 175 & \\
\hline
\end{tabular}

Keterangan:

TMS : Tidak Memenuhi Syarat

MS : Memenuhi Syarat

Berdasarkan tabel 1, variabel yang berhubungan dengan kejadian ISPA adalah status menyusui, status gizi, status imunisasi, penghasilan keluarga, ventilasi, jenis lantai, kepadatan hunian, dan ventilasi dapur. Sedangkan variabel yang tidak berhubungan dengan kejadian ISPA adalah jenis kelamin, kebiasaan merokok, pendidikan, pekerjaan, dan bahan bakar masak.

Tabel 2. Analisis Multivariat Faktor Kejadian ISPA

\begin{tabular}{lccccc}
\hline \multicolumn{1}{c}{ Variabel } & B & Wald & df & Sig & $\begin{array}{c}\text { Exp } \\
(\mathbf{B})\end{array}$ \\
\hline $\begin{array}{lccccc}\text { Status } \\
\text { menyusui }\end{array}$ & 1,951 & 26.987 & 1 & & \\
$\begin{array}{l}\text { Ventilasi } \\
\text { dapur }\end{array}$ & 0,219 & 0,143 & 1 & & \\
$\begin{array}{l}\text { Jenis lantai } \\
\text { Pendidikan }\end{array}$ & 0,532 & 0,558 & 1 & 0,001 & 7.036 \\
$\begin{array}{l}\text { Status } \\
\text { imunisasi }\end{array}$ & 1,484 & 0,404 & 1 & 0,395 & 1,703 \\
$\begin{array}{l}\text { Status gizi } \\
\text { Ventilasi }\end{array}$ & 1,007 & 1,641 & 1 & & \\
\hline
\end{tabular}

Berdasarkan tabel 2 didapatkan bahwa status menyusui merupakan faktor paling dominan terhadap kejadian ISPA karena memiliki nilai Exp (B) paling besar. Hasil analisis didapatkan OR dari variabel status menyusui adalah 7,036 artinya bayi yang menyusui tidak eksklusif akan menderita ISPA sebesar 7,036 kali lebih tinggi dibandingkan dengan bayi yang menyusu eksklusif setelah dikontrol variabel status gizi, status imunisasi, pendidikan, ventilasi, jenis lantai dan ventilasi dapur.

\section{Hubungan Status Menyusui dengan Kejadian ISPA pada Bayi Usia 4 sampai 6 Bulan}

Pada penelitian ini terdapat hubungan antara status menyusui dengan kejadian ISPA dengan nilai $\mathrm{p}=0,001$, dan dari uji multivariat didapatkan bahwa status menyusui merupakan faktor paling dominan mempengaruhi ISPA dengan nilai Exp (B) 7,036.

Penelitian ini sejalan dengan penelitian Rayes (1999) di Meksiko bahwa ada hubungan yang signifikan antara status menyusui dengan kejadian ISPA dengan nilai $\mathrm{p}=<0,001$ dan OR 5,14(2,29-11,6).Hal ini senada dengan penelitian Alarcon (1999) di Meksiko bahwa ada hubungan yang signifikan antara status menyusui dengan kejadian ISPA dengan nilai $\mathrm{p}=0,05$.

Adanya hubungan status menyusui dengan kejadian ISPA karena ASI banyak mengandung zat protektif mencegah infeksi pada bayi. ASI mengandung macam-macam substansi anti-infeksi yang melindungi bayi terhadap infeksi. Zat-zat anti infeksi dapat digolongkan dalam golongan spesifik dan nonspesifik. Didalam ASI terdapat banyak sel protektif, terutama pada minggu pertama laktasi seperti leukosit terdiri dari makrofag, limfosit T dan limfosit B. Fungsi limfosit untuk mensintesis antibodi IgA. sIgA ASI mengandung aktivitas antibodi terhadap virus saluran pernapasan dan pencernaan, dimana $\operatorname{IgA}$ melindungi membran pada saluran pernapasan. Selain sel terdapat juga faktor protektif larut seperti lisozim, laktoferin, sitokin, protein yang dapat mengikat vitamin B12, faktor bifidus, glycocompound, musim, enzim dan antioksidan. ${ }^{3,4}$

Hubungan Status Gizi dengan Kejadian ISPA pada Bayi Usia 4 sampai 6 Bulan

Pada penelitian ini terdapat hubungan antara status gizi dengan kejadian ISPA dengan nilai $\mathrm{p}=0,048$. 
Penelitian ini sejalan dengan penelitian Gozali (2010) yang mengemukakan bahwa ada hubungan yang signifikan antara status gizi dengan keajadian ISPA pada anak dengan nilai $\mathrm{p}=0,01$. Berbeda dengan penelitian Fakhriadi (2015) yang mengatakan bahwa tidak ada hubungan yang signifikan antara status gizi dengan kejadian ISPA dengan nilai $\mathrm{p}=0,052$.

Malnutrisi menyebabkan kelainan pada saluran napas sehingga mengganggu proses fisiologis saluran napas dalam hal proteksi terhadap agen penyakit. Pada anak dengan keadaan status gizi yang tidak normal maka proses fisiologi tidak akan berjalan dengan baik, sehingga agen penyakit yang seharusnya dikeluarkan tubuh menjadi masuk dalam saluran napas sampai paruparu.Pembentukan IgA sekretorik pada cairan mukosa saluran napas juga terganggu. IgA sekretorik pada anak dengan malnutrisi, menurun produksi dan fungsinya. Pertahanan tubuh seluler dan humoral menjadi terganggu menyebabkan agen patogen yang masuk tidak terdeteksi dan tidak dapat dikontrol. ${ }^{5}$

\section{Hubungan Status Imunisasi dengan Kejadian ISPA pada Bayi Usia 4 sampai 6 Bulan}

Pada penelitian ini terdapat hubungan antara status imunisasi dengan kejadian ISPA dengan nilai $\mathrm{p}=0,048$.

Penelitian ini sejalan dengan hasil penelitian yang dilakukan oleh Reyes (1999) di Meksiko yang menjelaskan bahwa ada hubungan yang yang signifikan antara status imunisasi dengan kejadian ISPA dengan nilai $\mathrm{p}=0,002$, OR 2,91(1,47-5,77).

Ada hubungan yang signifikan antara status imunisasi dengan kejadian ISPA karena vaksin merangsang sistem imun untuk memproduksi limfosit $\mathrm{T}$ dan antibodi, lalu tubuh akan dipenuhi limfosit $\mathrm{T}$ memori dan limfosit B yang akan mengingat cara untuk memerangi penyakit di kemudian hari. $^{6}$

\section{Hubungan Penghasilan Keluarga dengan Kejadian ISPA pada Bayi Usia 4 sampai 6 Bulan}

Pada penelitian ini terdapat hubungan antara penghasilan keluarga dengan kejadian ISPA dengan nilai $\mathrm{p}=0,020$.

Hasil ini berbeda dengan penelitian Alarcon (1999) di Meksiko yang mengatakan bahwa tidak ada hubungan yang signifikan antara status ekonomi dengan Kejadian ISPA dengan nilai $\mathrm{p}=0,37$.

Hasil penelitian terdapat hubungan yang signifikan antara penghasilan keluarga dengan kejadian ISPA. Karena orang yang mempunyai penghasilan tinggi akan memenuhi kebutuhan keluarganya baik sandang, papan, dan pangan. Berdasarkan tempat penelitian, keluarga dengan penghasihan tinggi lingkungan fisik rumahnya memenuhi syarat.

Hubungan Ventilasi Rumah dengan Kejadian ISPA pada Bayi Usia 4 sampai 6 Bulan

Pada penelitian ini terdapat hubungan antara ventilasi rumah dengan kejadian ISPA dengan nilai $\mathrm{p}=0,04$

Penelitian ini sejalan dengan penelitian yang dilakukan oleh Nurhidayati (2009) yang mengatakan bahwa terdapat hubungan yang signifikan antara ventilasi dengan kejadian ISPA, dengan nilai $\mathrm{p}=0,000$ dan OR 5,125 (2,261-11,619).Hasil ini tidak sejalan dengan penelitian yang dilakukan oleh Astrid (2014) yang menemukan dalam penelitiannya bahwa tidak ada hubungan yang signifikan antara ventilasi rumah dengan kejadian ISPA dengan nilai $\mathrm{p}=$ 0,264

Ventilasi rumah berhubungan dengan kejadian ISPA karena sirkulasi udara rumah yang baik akan mengurangi kadar partikulat, selain itu ventilasi yang baik dapat membebaskan udara ruangan dari bakteribakteri terutama bakteri patogen, karena melalui ventilasi terjadi pertukaran aliran udara terus-menerus sehingga bakteri yang 
berada didalam ruangan akan mengalir keluar. Selain itu ventilasi yang baik menjaga agar ruangan rumah pada kelembapan yang optimum. Ventilasiyang tidak baik akan menyebabkan kelembapan udara didalam ruangan naik dan bakteri dapat berkembang dengan baik. ${ }^{6}$

Hubungan Jenis lantai Rumah dengan Kejadian ISPA pada Bayi Usia 4 sampai 6 Bulan

Pada penelitian ini terdapat hubungan antara jenis lantai rumah dengan kejadian ISPA dengan nilai $\mathrm{p}=0,035$.

Penelitian ini serupa dengan penelitian Reyes (1999) di Meksiko bahwa ada hubungan yang signifikan antara lantai dengan kejadian ISPA dengan nilai $\mathrm{p}=$ 0,040, dengan OR 2,37(1,04-5,42). Begitu juga dengan penelitian Nurhidayati (2009) dalam penelitiannya mengatakan bahwa ada hubungan yang signifikan antara jenis lantai dengan kejadian ISPA pada anak, dengan nilai $\mathrm{p}=0,000$ dan OR 4,986 (2,16411,486).

Dari hasil penelitian bahan lantai terluas responden sebagian besar menggunakan plester kasar, sehingga banyak ditemukan lantai rumah dalam keadaan berdebu. Jenis lantai yang setengah plester mempengaruhi kelembapan rumah. Lantai yang tidak rapat air dantidak didukung dengan ventilasi yang baik dapat menimbulkan peningkatan kelembaban dan kepengapan yang akan memudahkan penularan penyakit. Kelembapan udara didalam ruangan naik karena terjadi proses penguapan cairan dan kelembapan merupakan media yang baik untuk bakteri, sehingga bakteri mudah berkembang biak dan menyebabkan kejadian infeksi pada bayi. ${ }^{6}$

Hubungan Kepadatan Hunian dengan Kejadian ISPA pada Bayi Usia 4 sampai 6 Bulan

Pada penelitian ini terdapat hubungan antara kepadatan hunian dengan kejadian ISPA dengan nilai $p=0,039$.
Penelitian ini sejalan dengan penelitian Nurhidayati (2009) dalam penelitiannya mengatakan bahwa ada hubungan yang signifikan antara kepadatan hunian dengan kejadian ISPA dengan nilai $\mathrm{p}=0,001$ dan OR 4,235 (1,908-9,402). Penelitian ini berbeda dengan penelitian yang dilakukan oleh Soolani (2013) yang mengatakan bahwa tidak ada hubungan antara kepadatan hunian dengan kejadian ISPA pada anak dengan nilai $\mathrm{p}=1.000$.

Kepadatan hunian berhubungan dengan kejadian ISPA karena kepadatan penghuni yang tidak memenuhi syarat akan dapat meningkatkan frekuensi kontak antara orang yang menjadi sumber penularan dengan orang yang rentan terutama bayi karena sistem imun bayi yangmasih rendah.Keberadaan mikroba diudara tidak bebas karena aliranudaratidak terlalu besar. Oleh karena itu, mikroba dapat berada di udara relatif lama. Dengan demikian kemungkinan untuk memasuki tubuh semakin besar. Hal ini dibantu pula oleh adanya kepadatan penghuni ruangan, sehingga penularan penyakit infeksi lewat udara sebagian besar terkena lewat udara tak bebas. ${ }^{7}$

Hubungan Ventilasi Dapur dengan Kejadian ISPA pada Bayi Usia 4 sampai 6 Bulan

Pada penelitian ini terdapat hubungan antara ventilasi dapur dengan kejadian ISPA dengan nilai $\mathrm{p}=0,038$. 
Adanyahubunganantaraventilasidapurde ngankejadian

ISPA karenaapabilaventilasidapurtidakmemenuhis yaratuntukmengeluarkanasapdanpartikelpartikeldebudaridapur, maka asap akanmemenuhiruangandanmenyebabkansirk ulasiudara di dalamruangantidakbaik. Apalagiibuseringmemasakdenganmenggend onganak, makaasapmengganggupernapasanpadaanakd anmenyebabkankejadiankesakitanpernapasa npadaanak

\section{SIMPULAN}

Status menyusui merupakan faktor paling dominan mempengaruhi ISPA, karena didalam ASI terdapat banyak sel protektif, terutama pada minggu pertama laktasi seperti leukosit terdiri dari makrofag, limfosit $\mathrm{T}$ dan limfosit B. Fungsi limfosit untuk mensintesis antibodi IgA. sIgA ASI mengandung aktivitas antibodi terhadap virus saluran pernapasan dan pencernaan, dimana IgA melindungi membran pada saluran pernapasan.

\section{UCAPAN TERIMAKASIH}

Penulismengucapkanterimakasihkepada Kepala Dinas Kesehatan Kabupaten Pasaman beserta Pimpinan Puskesmas di Wilayah Kerja Kabupaten Pasaman.yang telah memberikan kesempatan untuk melakukan penelitian. Penulisjugamengucapkanterimakasihkepada Petugas Kesehatan setempat yang telah membantu peneliti dalam melakukan penelitian.

\section{REFERENSI}

1 Arifeen, S., Black, R. E., \& Antelman, G. Exclusive Breastfeeding Reduce Acute Respiratory Infection and Diarrhea Deaths Among Infants In
Dhaka Slums. Official Journal Of The American Academy Of Pediatrics. 2001

2 Alarcon, Mardya, Salvador. BreastFeeding Lower The Frequency and Duration of Acute Respiratory Infection and Diarrhea in Infant under Six Month of Age. American Society For Nutritional Sciences. 1997

3 Astrid. Exposure to Envvironmental Factors with Acute Respiratory Infection (ARI) Among Children Under Five Years at Hamlet 1 of Ciampea Village. Globallimunators. 2013.

4 Badan Pusat Statistik. Survei Demografi dan Kesehatan Indonesia. Jakarta. 2012

5 Bates, Michael. Acute Lower Respiratory Infection in Childhood and Household Fuel Use in Bakhtapur, Nepal. Enviromental Health Perspectiv.2013

6 Chen, Yinxi. Risk Factors for Acute Respiratory Infection in the Australian Community. 2014

7 Cogswell, J. J., Halliday, D. F., \& Alexander, J. R. Respiratory Infections in the Year of Life in Children at Risk of Developing Atopy. British Medical Journal.1982

8 Dharmage, S. C., Rajapaksa, L. C., \& Fernando, D. N. Risk Factor of Acute Lower Respitratory Tract Infection in Children Under Five Years Of Age. Southes Asian J Trop Med Public Health. 1996

9 Fakhriadi. Factor Associated with Infection Disease Acute Respiratory Infection to Children in the Area Work of Bukit Hindu Publick Health Center.Building Health Community.2015.

10 Gozali, Achmad. Hubungan Antara Status Gizi dengann Klasifikasi Pneumonia pada Balita di Puskesmas Gilingan Kecamatan 
11 Hall, \& Breese, C. Nosocomial Respiratory Syncytial Virus Infection : The Cold War Has Not Ended. Oxford Journal. 2015.

12 Mataram, I. K. Aspek Imunologi Air Susu Ibu. Ilmu Gizi. 2011;37-48

13 Morley, C. J., Thornton, A. J., \& Fowler, A. M. Respiratory Rate and Severity of Illness in Babies Under 6 Months Old. Archives of Disease in Childhood.1990.

14 Newburg, David. Bioactive Components Of Human Milk. LLC. 2001.

15 Nurhidayati, Istianna. Lingkungan Fisik Rumah dengan Kejadian Penyakit ISPA pada Balita di Wilayah Kerja Puskesmas Karangnongko Kabupaten Klaten.2009.

16 Pickering, Larry., Morrow, Ardythe., Palacios, Guillermo.. Protecting Infants Through Human Milk. LLC.2002.

17 Reyes, Hortensia. Infant Mortality Due To Acute Respiratory Infection : The Influence off Primary Care Processes. Oxford University Press. 1997.

18 Sazaly, O., Lubis, B. M., \& Sianturi, P. Dampak Proteksi ASI Ibu Terhadap Infeksi. Jakarta: Sari Pediatri ; 2009.hlm. 167-73

19 Soolani. Hubungan Antara Faktor Lingkungan Fisik Rumah dengan Kejadian Infeksi Saluran Pernapasan Akut Pada Balita di Kelurahan Malalayang Kota Menad.2013.

20 Wati, Erna. Hubungan Episode Infeksi Saluran Pernapasan Akut dengan Pertumbuhan Bayi Umur 3 sampai 6 Bulan; 2005

21 Wempie, Y. Penyakit Infeksi Saluran Pernapasan Akut. 2013. (Diunduh 04 Maret 2015). Tersedia dari penkeskami. blogspot.com/penyakit-infeksipernapasan.html.

22 Puskesmas Karangnongko Kabupaten Klaten; 2009. 